\title{
Crossing boundaries of time and language: A discussion of the reception and translations of Martin Luther's hymn A mighty fortress in the context of the commemoration of the Reformation 2017
}

\begin{tabular}{|c|c|}
\hline $\begin{array}{l}\text { Author: } \\
\text { J. Gertrud Tön }\end{array}$ & $\operatorname{sing}^{1}$ \\
\hline $\begin{array}{l}\text { Affiliation: } \\
{ }^{1} \text { Department } \\
\text { Practical and } \\
\text { Theology, Coll } \\
\text { Sciences, Univ } \\
\text { South Africa }\end{array}$ & $\begin{array}{l}\text { f Philosophy, } \\
\text { jystematic } \\
\text { ege of Human } \\
\text { ersity of }\end{array}$ \\
\hline $\begin{array}{l}\text { Correspondin } \\
\text { J. Gertrud, } \\
\text { gertrud.tonsin } \\
\text { com }\end{array}$ & $\begin{array}{l}\text { g author: } \\
\text { g@googlemail. }\end{array}$ \\
\hline $\begin{array}{l}\text { Dates: } \\
\text { Received: } 09 \text { I } \\
\text { Accepted: } 31 \\
\text { Published: } 10\end{array}$ & $\begin{array}{l}\text { May } 2017 \\
\text { Aug. } 2017 \\
\text { Nov. } 2017\end{array}$ \\
\hline $\begin{array}{l}\text { How to cite th } \\
\text { Tönsing, J.G., } \\
\text { boundaries of } \\
\text { language: A di } \\
\text { reception and } \\
\text { Martin Luther } \\
\text { mighty fortres } \\
\text { of the comme } \\
\text { Reformation } 2 \\
\text { Teologiese Stu } \\
\text { Theological St } \\
\text { a4643. https:/ } \\
\text { 10.4102/hts.V }\end{array}$ & $\begin{array}{l}\text { is article: } \\
2017 \text {, 'Crossing } \\
\text { time and } \\
\text { scussion of the } \\
\text { translations of } \\
\text { 's hymn } A \\
\text { s in the context } \\
\text { moration of the } \\
017 \text { ', HTS } \\
\text { dies/ } \\
\text { udies 73(4), } \\
\text { /doi.org/ } \\
73 \text { i4.4643 }\end{array}$ \\
\hline $\begin{array}{l}\text { Copyright: } \\
\text { (C) 2017. The } \\
\text { Licensee: AOS } \\
\text { is licensed un } \\
\text { Creative Comr } \\
\text { Attribution Lic }\end{array}$ & $\begin{array}{l}\text { uthors. } \\
\text { S. This work } \\
\text { ler the } \\
\text { nons } \\
\text { ense. }\end{array}$ \\
\hline Read online: & \\
\hline 回神回 & $\begin{array}{l}\text { Scan this QR } \\
\text { code with your } \\
\text { smart phone or } \\
\text { mobile device } \\
\text { to read online. }\end{array}$ \\
\hline
\end{tabular}

The process of transmission and translation of texts has similarities with crossing borders into foreign territory, as immigrant or refugee. Not everything can be taken along, and finding acceptance in the new environment is sometimes difficult. Martin Luther's hymn A mighty fortress has found a place in most denominational hymnals, but there are many disagreements about how it should be sung and what its meaning is. Has it really found a 'home' in the new settings, or is it still a foreigner? Does it have a 'home' even in its original language in the 21st century? Can this hymn be a unifying factor in the Reformation celebrations in 2017? This article analyses various translations and discusses issues of interpretation of this well-known Reformation hymn.

\section{Introduction}

In 2017, churches throughout the world commemorate the Reformation. The movement that began with the posting of Martin Luther's 95 Theses in Wittenberg, Germany, spreads across the Western World and left the world more free-thinking and less dominated by oppressive religious institutions. But, it also left the church deeply divided. These divisions have not been overcome. They were exported with colonialism and the missionary movements, and have left divided and fragmented new Christian churches all over the globe. In spite of a growing ecumenical movement, the divisions are still deep. These divisions are present not only between the denominations but even within the Lutheran family. ${ }^{1}$ For Lutherans, it was fairly clear that singing hymns of the Reformation, particularly by Martin Luther, needed to be part of such a commemoration, and $A$ mighty fortress (LBW 228) ${ }^{2}$ is undoubtedly the most universally known and translated hymn of Luther. But, is it really a hymn that can bring Christians or even Lutherans together? Is it a mark of identity and unity? Do the new churches 'own' it or is it simply a 'colonial import' which one tolerates if one happens to be a Lutheran? ${ }^{3}$ Even in many German Lutheran congregations in South Africa, it is sung without fail on Reformation Day, but almost never at any other time during the year. ${ }^{4}$ This article will discuss the reception and translations of this hymn which was an important element in commemorations across the world. Starting with a brief discussion of translation theory, it traces the difficulties for translators based in the tune, the meter and the theological ideas of the hymn. The research focused on printed material in hymnals and the Internet, using comparisons and content analysis. Some reference is made to the author's own experience; however, no formal interviews or surveys are included in this article. The article ends with a suggested composite translation, usable in Reformation services.

\section{Translations - Crossing boundaries}

Before looking at the translations themselves, it is necessary to reflect more generally on the process of translation. Just as they cross the boundaries of time, hymns cross the boundaries of culture and language. In our multilingual world, translation is inevitable and an absolute necessity, not only for hymns. If language communities do not want to stagnate, they need

\footnotetext{
1.On 27 August, a service to commemorate 500 years of Reformation was held in Pretoria. It was hosted by six different Lutheran churches. Although the preparations were not without tensions, it was a breakthrough as these churches seldom celebrate services together.
}

2.Following hymnological convention, hymnals and song books are cited by abbreviation rather than editor.

3.This article was originally delivered at a Conference of the Society for Practical Theology in South Africa, with the theme 'Decolonising Practical Theology' January 2017.

4.This is in the experience of the researcher who has been a member, pastor or guest preacher at several German-speaking Lutheran congregations. Leaving it out once on Reformation Day drew definite protest. 
community and exchange with others, and this usually involves translation of some kind. The progress of civilisation has always involved translation (Longland 1977:67). Although translation is a necessity, it is also very difficult and always involves some loss of meaning and feeling. There may also be the feeling of imposition and cultural domination. The feeling of not quite fitting in the new cultural environment can be particularly painfully felt in hymn translation.

Lina Mounzer, a Syrian woman refugee, wrote about the work of translating the stories of Syrian women into English (Mounzer 2016). She uses a powerful metaphor for translation which definitely rings true for hymn translation. She uses her own experience of travelling across borders as an image of the work of translation:

[The women's] writing is filled with crossings; they are constantly traversing borders both visible and invisible, and it makes me think about the one between these two languages, Arabic and English, each a landscape unto itself. I am also hoping that what I am allowed to smuggle through will survive the journey...

When my family and I washed up in Canada, carried out on the great wave of migration away from the civil war in Beirut, I found that I could no longer unlock the trunk in which I carried the words to explain where I had come from, what I had lived. When I did manage to force it open, what I found inside was soggy, useless. The words were all in another language, nonnative to this new soil. I translated them as best as I could ... But the new words were strangely light. They carried none of the weight of what they truly meant. (Mounzer 2016)

Even for less traumatic translation situations, Mounzer's image is an appropriate one. The process of translating a work of literature, in this case a hymn, is almost like one of immigration. Some works come to be 'at home' on the foreign soil, becoming a natural part of that nation's culture. Others always retain their foreignness. Even after many years, even generations on foreign soil, they are still identifiably a different culture.

There are hymns and songs which have completely made their home in the new language, and one forgets that they are translations, such as O Lord my God from Swedish, Silent Night from German or O come all ye faithful from Latin (UMH $77,239,234)$. Many others hymns are sung but do not become part of genuinely local culture. This is the case, in the experience of the author, with many Lutheran traditional hymns which have been translated into the vernacular, but are sung correctly but not enthusiastically by African congregations.

Although all translation is difficult, translating hymns is particularly difficult, as they are not only poetic texts but also require adherence to a particular, often foreign meter. One has to accept the fact that one will not be able to take everything 'across the border'. The inevitable loss, and subtle or not so subtle shifts in meaning have led to an often quoted Italian Wordplay traditore tradutore equating translation with treason (Weinberger 2013:21). Even harsher is a little verse by Ephraim MosesKuh (1731-1790) who calls translating the old poets 'killing the dead's (quoted in Koller 1979:49). Undoubtedly, a translation can stifle the life in a literary work, or it can open it up to a whole new world. This is most obviously so in literary and poetic texts, and very much in hymns. Henkys (1998:182) argues that a successful hymn translation should be able to be read aloud as a poem, and obviously should be singable.

In general, one can distinguish three basic types of translations: The literal translation, as we find it in the interlinear bible; the 'faithful' translation, which aims to be as accurate as possible while smoothly flowing in the target language; and the 'free' translation, which brings across the central theme and message, while being very free with the exact words and ideas used to accomplish this. ${ }^{6}$ All three types are found in hymn translations.

\section{The tune of $A$ mighty fortress}

Relevant to the issue of translating the hymn, 'Ein feste Burg' is the question of tune and meter. Which tune or meter is used when translating the hymn into English? The question of tune is crucial in determining which hymns find a true 'home' in their new setting. This has been a complex question in the case of this hymn. Luther's original tune is rhythmically complex and almost dancelike. There is no fixed underlying rhythm, and it swings from duple to triple time and back. Although it is the much more interesting and attractive tune, it is normally judged 'too difficult' for the average congregant (EG 362 first tune). It is the clearest indication that Luther probably did not intend his hymn to be a 'battle hymn', as it is not a march-like tune. However, the Protestants appropriated it as their battle hymn, and perhaps for this reason, more than its degree of difficulty the tune was simplified to one with less dance-like rhythms. This second tune is simpler and more 'marchlike', but because one kept Luther's original meter, the tune still changes rhythm from duple to triple time (EG 362, second tune). When the hymn started to be translated, people who were no longer bound to Luther's exact text decided to simplify it even further to a simple $4 / 4$ time the whole way through. This is the so-called isometric tune. It is the common version in most nonLutheran hymnals (e.g. A \& M 114 and UMH 110). But, you cannot easily sing Luther's original words to this tune, so Lutherans have a problem with it. This means that while the ecumenical family can sing together, there is no agreement among Lutherans. Almost all Lutheran Hymnals print at least two versions. Some hymnologists lament the demise of Luther's original tune. Cherwien argues one should return to it, as it would eliminate some of the martial atmosphere of the hymn (2014:396). With most people being familiar with the simpler tune, it is very difficult to sing the original in congregations except with a choir. The German hymnal prints the original and the second version (EG 362), as does

5.Du übersetzt die alten Poeten?/Das heißt wohl recht, Gestorbene töten (Koller 1979: 49).

6.Koller (1979:68) distinguishes three types of translation according to how dependable and artistic they are. Übersetzung (literal translation) is dependable but not artistic, Übertragung [faithful translation] is dependable and artistic, and Nachdichtung (free translation) is artistic but not dependable. 
the Australian English one (LH 195). However, in the American Lutheran Hymnal, both the older and the new edition print the original Luther tune (LBW 228 and ELW 503) followed by the more ecumenical tune (229 and 504). In all these cases, the original Luther tune is probably not sung often, although it is printed. It is clear that when you export your culture into a new place, you, at some stage, have to relinquish control of what the recipients do with it. The rest of the world has in some ways decided to 'own' the Luther hymn, even if it is not sung often, but not on terms the Lutherans are altogether happy with. It is possible that Luther himself would not have minded as much as those who want to guard his legacy.

\section{Translations of the hymn}

Do the translations of Ein feste Burg 'kill' the original Luther hymn or give it a new lease on life? Is there a sense of 'effortless-sounding rightness' (Bernofsky 2013:229)? Were the most important ideas carried across the 'border'? The hymn definitely has a foreign-sounding meter. Firstly, it is the seven line 'bar form' which Luther often used, but also in the first half, the rhyme pattern is abab, with the main or second rhyming pair, the ' $b$ ' being one with 'feminine' or unaccented endings, which are a particular problem in English (see Longland 1977:76). This means it is more difficult to assimilate it completely in English.

A mighty fortress (LBW 228) or A safe stronghold (A \& M 114) is a hymn that has spread around the world and has been translated into countless languages. It is found in many Protestant hymn or song books that contain traditional hymns. ${ }^{7}$ Of course, its presence does not yet signify that it is actually 'owned' and sung regularly in the new community. However, many people from many denominations are aware of the hymn and probably would be able to sing it in the isometric version at a Reformation commemoration. There are three main translations in English. The one most Lutheran translations are based on, is Catherine Winkworth's translation, A mighty fortress, published in 1854 in Lyra Germanica and using the non-isometric tune ${ }^{8}$ (Winkworth n.d.). It was probably in circulation for a while before publication, because the other English translators seem to have been familiar with it. ${ }^{9}$ The translation by Frederick Hedge, $A$ mighty fortress, was published in 1853 (UMH 110). The one by

7.It is found in all the denominational hymnals i have looked into. In 1940, it was
found in all denominational hymnals, even the Catholic hymnals as argued by Hornaday (1940:122).

8.The Lutheran Hymnal of Australia cites as translator 'Church book, Philadelphia', but it is an only slightly modified version of Catherine Winkworth's translation (LH 195). The Lutheran Book of Worship of the USA cites as translator, 'hymnal version'. This is a more substantial revision of Winkworth, both in the original meter (LBW 228) and changed to isometric rhythm (LBW 229). The later edition of the American Lutheran Hymnal, Evangelical Lutheran Worship, gives LBW as translation source and does not change the Winkworth revision of the LBW (ELW 503, 504).

9.It seems likely that Winkworth was the first version in circulation, known by the others, as sometimes Hedge, sometimes Carlyle follows Winkworth's wording, but the other two never agree with each other over against Winkworth. Some examples where the translations are similar: Hedge against Winkworth. Some examples where the translations are similar: Hedge agrees with Winkworth: 'A mighty fortress', 'on earth is not his equal', 'One little word shall fell him' (Winkworth: 'can fell him'). Carlyle agrees with Winkworth: 'a trusty shield and weapon', 'that hath us now o' 'Not they can overpower us' (Winkworth, 'They cannot overpower us'.) 'And though they take our life, / Goods, honor, children, wife,' (Winkworth, 'And take they ou life, / Goods, fame, child and wife').
Thomas Carlyle is entitled A safe stronghold our God is still (A \& M 114). Both of these use the isometric tune.

There are many other translations. Wikipedia claims this hymn has been translated more than 70 times into English (Wikipedia n.d.), ${ }^{10}$ but most versions have not been included in popular hymnals.

However, one more version was found on the Internet, which is a translation for choirs wanting to sing the Bach Cantata Ein Feste Burg (Farseth 2009). On this website, there are three texts side by side: The words of the Bach Cantata in German, including the Luther Chorale; a very literal translation of the German words; and a rhymed singable version, which can be sung to the Bach music but does not flow very smoothly and is unlikely ever to be used on its own.

\section{Battle hymn or hymn of trust}

Central to the interpretation of the hymn and therefore also to its translation is the question whether it is a 'hymn of trust' or the 'battle hymn of the reformation'. Luther's tune was not very battle like, and Schulz argues that if Luther intended it as a battle hymn, 'he would certainly have given it an appropriate title' (Schulz 1969:303). In the early hymnals, it is always marked as being based on Psalm 46, a 'Psalm of Comfort' (Von Meding 1993:32). Both in the Psalm and in the hymn, no-one is called to fight, but it is God who is the defender, who 'breaks the rod, and shatters the spear' (Ps 46) or 'fights for us/breaks the cruel oppressor's rod' (LBW 228). This would be in line with Luther's position that Christians should fight only with the word. ${ }^{11}$ The hymn is based only very loosely on the psalm, leading some hymnologists to doubt the connection (e.g. Violet and Brecht, discussed in Mager 1986:87-88). However, others show that the hymn is a free Christian interpretation of the psalm (Mager 1986:92), and there is a deep connection, although the hymn cannot be called a versification of a psalm'. The Old Testament scholar Jüngel argues in a sermon on Psalm 46 that this is a hymn of trust, not a 'marching order' and that Luther would have 'sung his song to the lute, cautiously, tenderly and heartfelt' (Jüngel 2005:91).

However, there are many militant images in this hymn which seem to go beyond mere defence and protection, such as the words Wehr und Waffen [Defensive shield and weapon]. Or the words in v2 Es soll uns doch gelingen which is translated by Winkworth as They shall not overpower us (Winkworth n.d.) but is actually an active statement of overcoming (literally, we should succeed or even we must succeed). 'We should not fear, but will succeed' of course raises the question, 'succeeding at what?' It may mean, 'succeed at staying faithful', but can easily be interpreted as success in a battle. Mager argues that it is also Luther's own combative attitudes which contributed to the hymn's designation as a 'battle hymn' (Mager 1986:95).

10.This claim could not be corroborated by other sources.

11.This is argued, for example, in his Invocavit sermon (Luther 1522: LW 51:76). 
There are many controversies around the time it was written and speculation about what exactly inspired the song. Many have related the verse about the devils, to a quote by Luther about the Diet of Worms and have thus dated the hymn to 1521; others argued that Luther wrote it while waiting for news from the Reichstag in Augsburg in 1530. ${ }^{12}$ Some of these witnesses date right back to the era of the Reformation (Kulp 1958:306-307). However, there is growing consensus that date of first publication is probably fairly close to the date of origin (Mager 1986:87). The first confirmed publication comes from 1529 (Von Meding 1993:32). ${ }^{13}$ It is clear that it became appropriated as a 'battle hymn' quite early after publication. The conflicts may have become less acute after Augsburg 1530 , but they were by no means over, and they were to continue for centuries. The Protestants appropriated this hymn to give them courage. As early as 1531, parodies of the hymn were sung by the peasants, equating the devils to the priests (Schulz 1969:303).

Undoubtedly, it is the triumphalist language of the hymn which made it a popular 'battle hymn'. Whether intentional or not, the division between 'us' on the one hand, and the 'devils' and 'they' (whoever, 'they' are in verse 4) on the other, places the hymn in the context of a battle between good and evil. It is a battle against the 'prince of this world' and his legions, who are easily identified with particular groups of people. This close identification makes reconciliation difficult. Most groups of singers since that time probably had no problem deciding who 'they' are. Cherwien traces some of the conflict-ridden history of this hymn, which was often sung in the context of war (2014:391) and became symbolic of the Nazi offensive, popular with the German Christians and even used as signature tune for Nazi propaganda on the radio (2014:393). However, this did not stop it becoming an inspiration also for the other side, often being sung by the Confessing Church (Biermann 2011:89). Otto Riethmüller, youth pastor and song writer and member of the Confessing Church during the Nazi era, entitled his collection of songs published in 1935, Wehr und Waffen, 'Shield and Weapon' - 50 songs of the struggling church (Scheffbuch 1999:36). The hymn can develop great power to comfort and inspire in such a situation. But one always needs to keep in mind that good and evil are never as clearly defined as we would like them to be.

\section{Interpreting verse 4}

A particular problem of translation is verse 4 with its language that excludes women, who have for centuries had to sing about 'them' taking our 'wife'. The language divides harshly into 'us' and 'them', and it seems to trivialise the earthly life and human loss. The English below is my own literal translation:

12.Cherwien quotes a story attributed to Nicholas Selnecker, who apparently wrote about Luther waiting for news from the Diet of Augsburg singing 'Ein feste Burg' with his lute (Cherwien 2014:388). This may be the origin of the speculation that it was written during this time. But it was published earlier than 1530.

13.It seems most likely that Luther was in great anxiety because of conflict on all fronts and the feeling that Reformation was losing its way, as well as the other dangers such as the Plague and the ongoing persecution by the Roman church, and wrote this hymn as a way to give himself courage to continue. If the hymn had been wrote this hymn as a way to give himself courage to continue. If the hymn had been
a 'poetic expression' of the conflict with Zwingli as Van Stam argues (2002:37), it would probably have gained a different title.
They should let the word be (let it stand) and they will not have any thanks from this

He is with us in the midst of what we are doing, with his spirit and his gifts. If they take our body, possessions, honour, child and wife Just let it go (lit. let it drive away), they don't have any benefit from this The Kingdom still must remain for us.

It is understandable that in a time when martyrdom was an ever-present reality, people dealt with it, by almost devaluing this life, at least making it of much less consequence than the hereafter. But this is probably not a theology that one would want to encourage today. It needs to be said that Luther's theology placed a much higher value of the life and gifts of the ordinary existence than was the case in earlier theology. ${ }^{14}$ But, this does not come across in this verse.

The combative tone of the verse has led Schulz to argue that this verse was a later addition, which changed the intended tone from a hymn of comfort to a battle hymn. He writes ' $f f]$ or it seems certain, from the internal evidence adduced in the preceding pages, that the fourth stanza is a later addition to the hymn - whether by Luther or by someone else is immaterial in the present context' (Schulz 1969:311). Jenny argued in a similar way and advocated deleting verse 4 (Mager 1986:94). However, these are strange arguments. If Luther added it himself, it was added before the first publication. And as Luther authenticated his own work consciously, in order to prevent people publishing things in his name which he disagreed with (Rössler 1990:44), it is highly unlikely that someone else could have added it. So, verse 4 has always, at least in the public realm, been an integral part of the hymn. In the experience of the author, the discomfort with singing verse 4 is fairly widespread, even in traditional Lutheran circles. There is a well-known reference to this verse in the biography of the German hymn writer Jochen Klepper, who committed suicide with his Jewish wife and daughter, rather than let the Nazis 'take them' (Mager 1986:94). Van Stam quotes an incident from the 'table talks' (1563) where Luther himself admits that the verse seems to devalue his loved ones and insists that he would rather die himself than see them die (Van Stam 2002:60).

It is possible that if the poet had been a lesser individual than Martin Luther himself, this verse may have already been adjusted by the hymnal commission that revised several texts in the last edition of the German Lutheran Hymnal of 1994, even an archaic word in a text by Luther himself. ${ }^{15}$ However, translations into other languages have greater freedom.

\section{Comparisons of translations Literal or faithful}

The versions encountered for Ein feste Burg can generally be classed 'faithful' translations. None of them could be classified

14.In a treatise on good works, he argues that daily life and tasks are just as valuable as religious actions, (Luther 1520 LW 44:24)

15.In Luther's Pentecost hymn, Komm Heiliger Geist, der Hymnal Commission replaced the archaic and misunderstood word Blödigkeit (weakness) with the word Ängstlichkeit [fearfulness], which could be done without a change in meter or accent (EG 125). 
as a completely free translation. There is the literal translation by Farseth (2009). This one is grammatically clumsy and does not adhere to any meter. The second rhymed and singable version of Farseth is somewhere between an 'interlinear' and a 'faithful' version, as it does not reach the goal of smoothly flowing language, although it is singable. ${ }^{16}$ However, both Farseth versions serve their purpose of helping non-Germans understand the meaning of the words of the Bach Cantata.

The other translations by Winkworth, Hedge and Carlyle could all be classified as 'faithful' translations rather than literal translations, but they all remain fairly close to the original. Winkworth's translation is today usually used in various revised versions in Lutheran hymnals. These 'faithful translations' seldom sacrifice rhyme outright, but do take some liberties, such as Winkworths 'weapon' and 'overtaken' (Winkworth n.d.), which Carlyle also uses (A \& M 114) and Hedge's 'God' and 'flood' (UMH 110). They all take liberties in the grammar, sometimes to the point of clumsiness. ${ }^{17}$ This makes them less likely to be completely 'at home' in the target community. There is little verbal reference to Psalm 46, as it was obviously more important to the translators to capture Luther's image faithfully than to remind their target audience that this hymn was based on a psalm, particularly as the hymn is based only very loosely on the psalm. Closest is the revision of Winkworth in the Lutheran Book of Worship: 'he breaks the cruel oppressor's rod', which is close to Psalm 46 's, 'he breaks the rod, and shatters the spear' (LBW 228). Here, the LBW revision, while being less close to the words of Luther, is closer to his intention, by invoking - at the same place in the hymn, the language of Psalm 46. This is an example of 'comparable effect' (Longland 1977:71) which makes for a flowing but still faithful rendition of the original.

Luther himself clearly favoured faithful translation, in some places even free translation over literal translation. After his Bible translations were attacked for not being accurate translations of the original, he wrote his Sendbrief vom Dolmetschen (An Open Letter on Translating). Here he argues that one should not look at the Latin when asking how to translate into German:

... we must ask the mother in the home, the children on the street, the common person in the market about this. We must be guided by their tongue, the manner of their speech, and do our translating accordingly. Then they will understand it and recognize that we are speaking German to them. (Luther 1530)

For Luther, it was more important that the target community recognises the text as 'their' language than that it is verbally accurate. Of course, even a fairly free translation still needs to convey the basic intention of the original hymn in a faithful way.

16.The phrase "The prince of this world, How sour he comes on! Yet he harms us none is a fairly clumsy, yet fairly literal translation. 'Brute force and deceipt strew victims at his feet' is a line where Farseth abandons literal translation for the sake of rhyme. The second of these lines speaks about the 'terrible armour' of the foe, not of his victims (Farseth 2009).

17.Places where the grammar does not flow smoothly are, for example, Winkworth's line, 'He helps us free from every need that hath us now o'ertaken' (Winkworth n.d.), or Hedge's 'Our helper he, amid the flood / of mortal ills prevailing' (UMH 110) and Carlyles lines: 'With force of arms we nothing can, / full soon were we $110)$ and Carlyles lines: 'With force of arms we nothing can, / full soon were we
down-ridden;', 'Ask ye, who is this same? Christ Jesus is His Name' and 'We lay it down-ridden;', 'Ask ye, who is this same? Christ Jesus is His Nan
not to heart so sore; not they can overpower us' (A \& M 114).

\section{Dealing with militancy}

All three translations stay largely with Luther's intention that this is a hymn of trust that God will fight our battles and defend us. They take up the underlying militancy in different ways, sometimes deliberately or unconsciously softening the militant language. 'Ein feste Burg' literally means a strong or solid fortress. Winkworth one could argue is even slightly more militant than the original with her 'mighty fortress', which Hedge also uses. Carlyle uses 'safe stronghold', which perhaps is more accurate, but leaves out the strong image of the Luther hymn. Both Winkworth and Carlyle include both 'shield' and 'weapon', but Hedge leaves out the weapons. For the rest of the verse, most translations stay fairly close to the original, but some specify more clearly who the 'old evil foe' is, such as LBW's isometric version, 'the old satanic foe', or Carlyle's 'the ancient prince of hell'. This is true to Luther's intention, as the later Fürst dieser Welt, 'prince of this world' is a clear reference to Satan, and hordes of devils populate verse 3 .

For Luther's ambiguous line 'We should not fear, but will succeed', Hedge gives a clearer but still ambiguous line: 'We will not fear, for God has willed/His truth to triumph through us' (UMH 110). Just as in Luther, this shows we are not passive, but part of God's victory but it does not directly call people into battle. Here Hedge is probably closest to Luther's intention. Winkworth takes out the action of humans: 'We tremble not, we fear no ill,/They shall not overpower us' (Winkworth n.d.). Carlyle's goes in a similar direction but rather less smooth: 'We lay it not to heart so sore;/Not they can overpower us' (A \& M 114). Both of these keep the human passive, not involved in God's action, simply trusting.

\section{Subtle theological shifts}

The translations of verses two and three are with few exceptions almost literal in all three basic versions, as well as the revision of Winkworth in the LBW. There are few direct correspondences between Winkworth and the other two versions. One subtle shift in meaning occurs in the second to last line in verse 2: Winkworth's rendition is fairly literal, 'Of Sabaoth Lord,/And there's none other God' (Winkworth n.d.). The last phrase obviously refers to the Trinitarian controversy about the nature of Christ. This is not picked up in the other versions. Hedge has 'Lord Sabaoth his name, from age to age the same' (UMH 110) and Carlyle for reasons of rhyme probably shifts the term 'The Lord Sabaoth' away from Christ himself, calling him, 'The Lord Sabaoth's Son, He, and no other one' (A \& M 114). The LBW revision takes out the word Sabaoth, which is smoother in English, although it is not a literal translation.

\section{Verse 4}

All three translations leave in the ambiguous 'they'. Winkworth is closest to the text, keeping the life-wife rhyming couplet (Windworth n.d). Carlyle's version is almost identical except for his changes to isometric rhythm (A \& M 114). 
For reasons of inclusive language, the Lutheran Book of Worship revision changes the life-wife rhyming couplet to the following: 'If they take our house, goods, fame, child, or spouse' (LBW 228). Although the change makes the first part less forceful, it is probably a worthwhile change in order to make it less offensive to contemporary singers.

Hedge makes it more general and slightly changes Luther's order, which results in a less problematic but still fairly accurate rendition: 'Let goods and kindred go, this mortal life also/the body they may kill: God's truth abideth still. His kingdom is forever' (UMH 110).

All of these translations are faithful to Luther's original and probably to his intentions. However, the problem that this verse seems to devalue earthly life still remains. In this case, a more free revision of the text seems to be legitimate. The revision below shifts the emphasis towards the problem of dealing with loss, a real threat faced by persecuted people ${ }^{18}$ (see hymn text at the end of article).

\section{Conclusion}

The translations discussed above have not 'killed' the Luther hymn, but have not completely 'domesticated' it either. It has become an 'ecumenical' hymn, being included in many denominational hymnals, while not being completely at home in many of them. There are too many slightly jarring and clumsy passages to be completely comfortable in the new language. In the case of this hymn, translators have rather erred on the side of accuracy than smoothly flowing rhythm and rhyme. This is probably because of the status of its writer and its history. Perhaps it needs to remain as a slightly foreign historical icon, rather than a known and loved every day hymn.

It is likely that the hymn was sung in countless languages in various variations of the tune, all over the world in $2017 .{ }^{19} \mathrm{In}$ most of these celebrations, the isometric ecumenical tune probably held sway even among Lutherans, as most languages use the isometric version. Into the future, the hymn will probably still be sung for its symbolic value, in traditional and perhaps modernised rhythms, as in a recording by Brian Doerksen in the style of contemporary worship songs (Doerksen 2010). Perhaps in a world of increasing division and conflict, it could be sung with renewed passion. It is to be hoped that if the hymn is sung again with militant fervour, it will not lead to increased division between 'us' and 'them', but an increased willingness to stand up for what is right even if it carries a cost, to build unity among peoples.

In conclusion, the whole hymn is quoted below in a composite translation:

18.This is my own revision included in the unpublished song collection we sing of your love.

19.The author was involved in the preparation of several special services, and passed on the version printed at the end of this article. At the service in August 2017, the hymn was also sung in various languages using the isometric tune, and the English verses used this same translation.

\section{A mighty fortress is our God}

1. A mighty fortress is our God, / a sword and shield victorious. $\mathrm{He}$ breaks the cruel oppressor's rod and wins salvation glorious. The ancient evil foe, / now means such deadly woe. With craft and dreadful might / he arms himself to fight. On earth he has no equal.

2. No strength of ours can match his might! / We would be lost, rejected. But now the right man comes to fight, / by God himself elected. You ask who this may be? / The Lord of hosts is he. Christ Jesus, mighty Lord, / God's only son adored. He holds the field for ever.

3. Though hordes of devils fill the land, / and threaten to undo us; We will not fear, for God hath willed / His truth to triumph through us. While this world's prince may rage, / in fiercest wars engage, his might is doomed to fail; / God's judgement must prevail! One little word can fell him.

4. Despite all foes, the Word shall stand, / against all their endeavour. God's gifts and Spirit, close at hand, / shall be with us forever. If they would come one day / and take loved ones away, our life, and all we own, / we'll still not be alone. God's kingdom is forever.

\section{Acknowledgements Competing interests}

The author declares that she has no financial or personal relationships which may have inappropriately influenced her in writing this article.

\section{References}

A \& $M$, The Council of Hymns A \& $M$ (ed.), 2001, Hymns ancient and modern, Canterbury Press, Norwich. (Hymn Books).

Bernofsky, S., 2013, 'Translation and the art of revision' in E. Allen \& S. Bernofsky (eds.), In translation - Translators on their work and what it means, Columbia University Press, New York.

Biermann, M., 2011, 'Das Wort sie sollen lassen stahn...' - Das Kirchenlied im 'Kirchenkampf' der evangelischen Kirche 1933-1945, Vandenhoek \& Ruprecht, Göttingen.

Cherwien, S.P., 2014, 'Trutzlied or Trostlied? A hymnist looks at Martin Luther's "Ein feste Burg"', Word and World 34(4), 387-397.

Doerksen, B., 2010, A mighty fortress is our God - Video, viewed 05 April 2017, from http://player.mashpedia.com/player.php?ref=mashpedia\&q=21cpWEe3u4M

EG, Verlagsgemeinschaft für Niedersachsen/Bremen (ed.), 1994, Evangelisches Gesangbuch, Vandenhoek \& Ruprecht, Göttingen. (Hymn Books).

ELW, Evangelical Lutheran Church in America (ed.), 2006, Evangelical Lutheran worship, Augsburg Fortress, Minneapolis, MN. (Hymn Books).

Farseth, P., 2009, Cantata BWV-80, Ein feste Burg ist unser Gott - Two English translations, viewed 11 October 2016, from http://www.bach-cantatas.com/ Texts/BWV80-Eng8.htm

Henkys, J., 1998, 'Gott loben mit einem Mund? Zur Nachdichtung fremdsprachlicher Kirchenlieder', Jahrbuch für Liturgik und Hymnologie 37, 179-195.

Jüngel, E., 2005, 'Sermon on Psalm 46', Consensus 30(1), 91-100.

Koller, W., 1979, Einführung in die Übersetzungswissenschaft, Quelle \& Meyer, Heidelberg.

Kulp, J., 1958, Die Lieder unserer Kirche - Eine Handreichung zum Evangelischen Kirchengesangbuch, rev. edn., Vandenhoeck \& Ruprecht, Göttingen.

LBW, Lutheran Church in America (ed.), 1978, Lutheran book of worship, Augsburg Publishing House, Minneapolis, MN. (Hymn Books)

LH, Lutheran Church of Australia (ed.), 1980, Lutheran Hymnal, Lutheran Publishing House, Adelaide. (Hymn Books)

Longland, J., 1977, 'World vast world of poetic translation', Latin American Research Review 12(1), 67-86, viewed 25 October 2016, from http://www.jstor.org/ stable/2502671

Luther, M., 1999, c1966 [1520], 'Treatise on good works', in J.J. Pelikan, H.C. Oswald \& H.T. Lehmann, (eds.), Luther's Works. Vol. 44: The Christian in society I, vol. 44, p. 24, Fortress Press, Philadelphia, PA.

Luther, M., 1999, c1959 [1522], 'Second Invocavit Sermon', in J.J. Pelikan, H.C. Oswald \& H.T. Lehmann, (eds.), Luther's works, vol. 51, p. 76, Fortress Press, Philadelphia, PA.

Luther, M., [1530], Marlowe, M.D. (revised and annotated), 2003, An open letter on translating, viewed 16 November 2016, from http://www.bible-researcher.com/ luther01.htm 
Mager, I., 1986, 'Martin Luthers lied, Ein feste Burg ist unser Gott' und Psalm 46', Jahrbuch für Liturgik und Hymnologie 30, 87-96.

Mounzer, L., 2016, War in translation: Giving voice to the women of Syria - Lina Mounzer on the urgency of telling the stories of conflict, viewed 10 November 2016, from http://lithub.com/author/lina-mounzer

Rössler, M., 1990, Liedermacher im Gesangbuch, Band I, Calwer Verlag, Stuttgart.

Scheffbuch, B. \& Scheffbuch, W., 1999, Den Kummer sich vom Herzen singen - So entstanden bekannte Lieder, Hänssler Verlag, Holzgerlingen.

Schulz, S., 1969, “'Ein feste Burg ist unser Gott”: Luther's treatment of the 46th Psalm' Colloquia Germanica 3, 302-315, viewed 19 December 2016, from http://www. jstor.org/stable/23980015

UMH, Job, R.P et al. (ed.), 2005, United Methodist Hymnal, United Methodist Publishing House, Nashville, TN. (Hymn Books).
Van Stam, P., 2002, 'Luthers Lied, "Ein feste Burg" - Mitten aus dem Abendmahlsstreit mit Zwingli entstanden', Nederlands Archief voor Kerkgeschiedenis/Dutch Review of Church History 1(82), 35-60.

Von Meding, W., 1993, 'Ein feste Burg ist unser Gott: Martin Luthers christliche Auslegung des Psalms 46', Zeitschrift für Theologie und Kirche 90(1), 25-56.

Weinberger, E., 2013, 'Anonymous sources - On translators and translation', in E. Allen \& S. Bernofsky (eds.), In Translation - Translators on their work and what it means, Columbia University Press, New York.

Westermeyer, P., 2014, "A mighty fortress" and Psalm 46 in context', Word and World 34(4), 398-407.

Wikipedia n.d., A mighty fortress is our God, viewed 10 April 2017, from https://en. wikipedia.org/wiki/A_Mighty_Fortress_Is_Our_God

Winkworth, C. n.d. 'A mighty fortress' - Translation, viewed 12 November 2016, from http://ingeb.org/spiritua/amightyf.htm 